\title{
THE NATURE OF CERTAINTY IN RITUAL
}

\author{
M I C H A E L A V L ČK OVÁ
}

\begin{abstract}
Liturgy is a privileged type of action: it is the actualisation of the Easter mystery, God's salvation of His people, and the thanksgiving and praise of the Christian community. At the same time, liturgy must be seen as human behaviour and very specific - ritual behaviour. This study focuses on the concept of liturgy as a ritual which allows the exploration of the anthropological, physical, and performative part of liturgical action. This article demonstrates the basic elements in which the nature of this certainty is based in ritual (certainty based on the body, on traditionalism, on the form and on the doctrine).
\end{abstract}

Key words

Liturgy; Ritual; Certainity; Ritual studies

DOI: $10.14712 / 23363398.2020 .4$

\section{$\mathbf{R}$}

ituals are of anoetical nature. Rituals do not aim to communicate a special message in a conscious, rational way. 'Religious rituals aim to immerse the whole of person in the world of that mysterious absolute, God, ${ }^{11}$ writes Anton Usher. The adjective anoetic means outside-the-intellect, rituals go side by side with meaning. Rituals do not have connections with thinking; rather they have a connection to the non-conscious parts of human beings - the motions, intuition, instinct, and the spiritual human being.

\footnotetext{
1 Anton Usher, Replenishing ritual: Rediscovering the place of rituals in Western Christian Liturgy (Milwaukee, Wisconsin: Marquette University Press, 1992), 14 nn.
} 
Christian rites are essentially rituals. This fact cannot be overlooked although we are aware of their specific nature that is given primarily by the fact that we do not consider individual Christians or rather an assembled communion to act in rituals, but also, and above all, God acting through Christ in the Holy Spirit. Liturgy is a privileged type of action: it is the actualisation of the Easter mystery, God's salvation of His people, and the thanksgiving and praise of the Christian community. At the same time, liturgy must be seen as human behaviour and very specific - ritual behaviour. In this study, we rely on the findings of ritual studies (and authors who approach their concept of ritual), which have been accepted by liturgists in recent years as useful and relevant also for the study of liturgical rites.

The concept of liturgy as a ritual allows the exploration of the anthropological, physical, and performative part of liturgical action. We do not want to diminish the importance of theological content and the liturgical-theological meaning of Christian rites; however, we also try to acknowledge their specific ritual character. Ritual is not based primarily on cognitive processes; it is not only a matter of interpretation and transmission of coded messages, meanings. Rituals are not even a place of moral, ethical distinction.

Rituals are not, in their essence, places to be faced with a dilemma of discernment between good and evil and to make crucial decisions. Rituals are usually given in advance. They are beaten paths, corridors channelling our actions, with predetermined content, regulated river beds, preventing meanders and dead ends. However, in some rituals, we express and confirm important discernments and decisions, especially those that are connected with privileged moments of our lives, with important life landmarks. The most typical are ceremonies of baptism, marriage, confirmation, consecration (commissioning in evangelical churches).

In the Catholic Liturgy of the Easter Vigil, believers renew their baptismal promises every year with those who are baptised, they renounce the spirit of evil and all his works, and express their faith in the Trinity. In every Lord's Prayer, which is a common element of worship across churches, they pray: and lead us not into temptation, but deliver us from evil.

In Christian rituals, we confirm everyday attitudes in the daily leaning towards good, which is the way of life of a Christian. This affirmation and strengthening is not just based on our will, rationality, and 
moral feeling. Rituals reinforce certainty of our attitudes and leaning towards good in their own specific way, which makes the ritual a ritual. Rituals are based on the human need for certainty - this is one of the 'textbook' definitions of ritual. Rituals provide certainty. In the following lines, we demonstrate the basic elements in which the nature of this certainty is based in ritual.

\section{Certainty Based on the Body}

Ritual is a physical activity. It means embodiment not just in terms of expressing certain content through symbolic actions, in the form of a text that could be decoded. Some anthropologists, based on the research of archaic cultures, incline to the opinion that rituals probably evolved from purely physical activities, which do not have to be based on myths, as is often assumed. The ritual dynamics emanates from the body itself as an authentic source of the ritual process. ${ }^{2}$

The pre-modern Church placed the human body at the centre of reflection of Christian life, identity and faith. This emphasis on embodiment is also expressed in the liturgical and ritual practices of the early and medieval Church. A wide range of demands for strengthening pious life (fasting, sexual abstinence, vigils) affected the body in perceptible ways. ${ }^{3}$ The best example is undoubtedly the rite of Christian initiation, where the bodily experience was the basis of ontological transformation, as Margaret Miles writes: 'The aim of religious practices was thus not to "act out" previously held ideas or beliefs, but to realise - to make real - a personal body, the strong experience, that together with the religious community's interpretation of that experience, produced a counter-cultural self."

Acts performed during the preparation and during sacramental ceremonies are often referred to in terms of physical changes and in metaphors reflecting physical activity. Ambrose describes the ceremony of prebaptismal anointing so that the catechumen has to be oiled as an athlete of Christ for the earthly struggle with evil. Cyril of Jerusalem ${ }^{5}$

2 Cf. Gerard Lukken, Rituals in Abundance. Critical Reflections on the Place, Form and Identity of Christian Ritual in Our Culture (Leuven: Peeters, 2005), 52.

3 Cf. David Torvell, Losing the Sacred. Ritual, Modernity and Liturgical Reform (Edinburgh: T \& T Clark, 2000), 48-49.

4 Marget Miles, Carnal Knowing (Tunbridge Wells: Burns and Oates, 1992), 24.

5 Cyril of Jerusalem, Catechetical Lectures, I, 4. 
explains that physical inversion by 180 degrees that makes the catechumen before baptism express the turning away from evil (the west symbolises Satan, evil) and conversion to good (the east symbolises resurrection and Christ himself). Discernment between good and evil and leaning to good were demonstrated and realised in a physical activity and cosmological categories (west, east, night, day, light, darkness).

Talal Asad, who dealt with rituals of monastic communities of the Middle Ages, shows that ritual in Benedict's rule assumed 'thinking' through the skin and 'speaking' with all human senses. The purpose of a ritual is to teach the body how to develop spiritual power in a material way. Ritual competence is a physical competence; it is a summary of embodied abilities, and not only just a mediator of symbolic meanings. Asad likens the skills to a pianist whose skilled hands are exercised to learn to play a song. ${ }^{6}$ Physical ritual practices can be seen as the precondition of religious experience. The decision to enter the communication with God follows the functions of the body. The experience rooted in bodily actions and perception helps to make that in ritual metaphysical realities touch the person on a different level than just rationally accepted and expressed truths.

\section{Certainty Based on Traditionalism}

The essential characteristics of most rituals are that they are transferred, passed down from generation to generation. Now their old origin often belonged to the properties guaranteeing their effectiveness. Rituals are important elements of cultural memory and content formula to solve some situations. We can give an example of transition rituals that surrounded transitional life situations in all cultures. As an example, we can mention the rites of a passage that surrounded transitional life situations in all cultures. They were sure and reliable ways taken from ancestors regarding how to handle the critical moments of human life, when one goes through the imaginary land of no one, through a dangerous zone between two worlds (a teenager is no longer a child, but he is not yet an adult). By carrying out these rituals, it was clearly expressed that the person had passed through this uncertain

6 Talal Asad, 'Toward a Genealogy of the Concept of Ritual,' in Genealogy of Religion, Discipline and Reasons of Power in Christianity and Islam (London: The Johns University Press, 1993), 62-63. 
stage and reached a new status. These rituals also interpreted these life changes, and expressed and confirmed important decisions and newly chosen directions at the crossroads of human life.

The basis of sincerity anchored in ritual traditionalism does not lie in a rational interpretation of ritual components. The certainty of the participants is more strongly based on non-rational, intuitive foundations. Chauvet mentions symbolic behaviour, such as Sunday churchgoing, that provides values and norms in society, and is all the more powerful for being less conscious. ${ }^{7}$ As the psychological and social motivations of Sunday practice become conscious, their effectiveness is destroyed. This effectiveness is based on 'self-evident, natural' bases built from early childhood that are not usually reflected upon. 'For the Christians of Europe as for the Bororos of Amazon or the Azandes of Ethiopia, the ritual symbols had no more justification than a "we don't know why, but it's always been done this way". 8

\section{Certainty Based on the Form}

Experts agree that the sincerity of a ritual lies beyond their control and possibility to shape it. The purpose of our action is given by tradition, lying in the past, beyond our reach. The course of the ritual is prescribed; the ritual has a predetermined form, which is not determined by the performers. ${ }^{9}$ By repetition and routine, the possibilities of participation in the ritual are deepened; the participants do not have to focus on the individual acts but on the inner content.

Besides repetition, essential in terms of form is also the hieratic character of ritual. The ritual always represents a kind of rupture, a boundary to be overcome - in the sense of disruption, stepping out of everyday life. Catherine Bell describes ritualisation as a practice connected to certain situations in which one of the basic strategies is to distinguish the sacred from the profane / the extraordinary from the ordinary. ${ }^{10}$ This distinction is usually given by a special (or sacred) space, by time,

7 Louis-Marie Chauvet, Symbol and Sacrament. A Sacramental Reinterpretation of Christian Existence (Collegeville: The Liturgical Press, 1995), 333.

8 Chauvet, Symbol and Sacrament, 335.

9 See Roy A. Rappaport, Ritual and Religion in the Making of Humanity (Cambridge: University Press, 2005), 24.

10 Cf. Catherine Bell, Ritual Theory, Ritual Practice (New York: Oxford University Press, 1992), 74 . 
when the ritual takes place (feasts, boundary moments during the day, and so on). This differentiation forms an essential part of ritualisation, as we see in the evolution of liturgical rites in the Middle Ages. Liturgical vestments differ from ordinary clothes, liturgical vessels no longer resemble commonly used dishes, and also the hosts are fundamentally different from ordinary bread. And the same, it is true of the liturgical language. In the liturgy of the Middle Ages, when the rites due to Latin and other barriers become ungraspable to believers, the form of a ritual prevailed over the content. Content in the large-scale escapes simple believers and less educated priests. On the other hand, making the content of the liturgy approachable in the context of the Second Vatican Council reform led to weakening of the power of ritual action. The mechanisms and functions of the ritual have been revealed, thereby its effect weakened. ${ }^{11}$

\section{Certainty Based on the Doctrine}

A ritual usually has a narrative basis. Eliade described how ritual emerges from mythical narration; it is an imitation of events that set the world and its order. ${ }^{12}$ During rituals, myths are narrated and mythological events are remembered and actualised. Thanks to myths, rituals gain their sense, meaning, and their binding character. The memory of the events of salvation, of God's saving deeds done for the benefit of God's people is the foundation of many feasts, and we can say it is the foundation of Jewish and Christian liturgy. Many Jewish and Christian liturgical prayers have an anemanetic-epicletical structure. In the anamnetic part, God's saving deeds in history are recalled and listed, and in the epicletical part, there follows a prayer to God in the Holy Spirit also to work in this way at that moment in the lives of the Christians participating in the liturgy.

Belief in God's help is based on biblical narratives about God's action in the history of salvation. Belief in the effects of liturgical ceremony comes from the New Testament's messages about Jesus' life and his actions. In Christian rituals, we often meet with Institutio narratives, ${ }^{13}$ telling about the constituting of liturgical events that have become the

11 Srov. Chauvet, Symbol and Sacrament, 335.

12 Cf. Mircea Eliade, Posvátné a profánní (Praha: Česká křestanská akademie, 1994; OIKOYMENH, 2006).

13 Lukken, Rituals in Abundance, 92. 
foundations of sacramental and other ceremonies. They can take place in different parts and elements of a ritual - in biblical readings, prayers, and liturgical acts. Typical are the words of institution in the middle of the Eucharistic Prayer. In the blessing of the water before baptism, there is a reference to Jesus' order that the disciples should baptise. In the wedding ceremony and blessing prayer over the bridegroom and bride, there is the narration about the creation of man as a man and a woman and about their unity and other references about marriage in the New Testament. In the development of the liturgical rites of the Reformation churches, their anchorage in Scripture has become an important criterion for understanding the sacraments.

In the Catholic tradition since the Middle Ages, the emphasis has been on the doctrine of grace that the sacraments contain and mediate. In the language of scholastic theology, the sacraments operate ex opere operato, having objective efficacy because Christ himself acts in them. The certainty in the ritual, its effectiveness in the life of the believer is thus also given rationally, by faith, by doctrine, whether based on biblical or scholastic theology; and it is not based only on narrative basis of ritual. In Jewish and later in Christian tradition, ritual regulations played an important role. Jesus is critical of the Pharisees, who regarded ritual laws of being of higher importance than moral behaviour. 'I ask you: What does our Law allow us to do on the Sabbath? To help or to harm? To save a man's life or destroy it?' (Lk 6, 9).

Early Christianity does not identify itself with the cult concept of liturgy. In the Middle Ages, however, a system of ritual prohibitions and orders was being developed which, in many ways, may remind us of the Old Testament regulations. Christianity also introduced statements regarding ritual purity: the 'tariff system' of penitence provided precise instructions how to undo any offenses against these orders.

Sunday attendance at worship became an obligation; the IV. Lateran Council set the duty to receive the Eucharist at least once a year and the like. Also, the Church has developed a system of ritual instructions and commands, the observance of which should ensure the proper life of a Christian. 


\section{Conclusion}

Certainty in rituals, anchored in corporeality, traditionalism, form and doctrine, can be a reinforcement but also a trap. In rituals, especially in rites of passage, accompanying transitional life situations, one touches the mysteries of human life. The goal of Christian rituals is to 'immerse the whole man in the divine mysteries' ${ }^{14}$ Meeting yourself and meeting God, which is unique in ritual, exposes a person to reflect on his everyday decisions and his way of life; it helps in orientation and discernment. In the ritual, this discernment and deciding is strengthened by certainty which comes from other sources than only rational, and touches man holistically.

Rituals can be strengthening in the search of security. In life situations and in long life stages, when there is no basic certainty, they can be supportive. If a person is not able in some situation or life stages to make discernment and the right decision, to undertake the right steps, conscious of his or her weakness and uncertainty, he or she can rely on a proven beaten path, immerse himself or herself in a safe stream, obey Christ's command or follow the example of parents and ancestors.

At the same time, this certainty can become a trap when it becomes irreversible and unreflected upon. Unilateral clinging to tradition, form, doctrine or unreflected-upon performance of external actions can lead to ritualism, emptying the inner content and meaning of the ritual, and to performing ritual acts without participants identifying with their content. Clinging to the outer form, tradition and doctrinal aspects may be a concealment of one's own insecurity, unwillingness, or reluctance towards responsible discernment.

We tried to identify significant resources through which human security is strengthened in ritual action. The cognitive dimension of ritual - in our text represented by doctrine, narrative, and ritual prescriptions - we put in the last place. This does not mean that we do not consider it essential in the ritual. But it does not have to be considered the most important.

In any case, this dimension of Christian rites is given the greatest, almost exclusive, attention in liturgical science. Taking into account the findings of ritual studies that emphasise the importance of

14 Usher, Replenishing ritual, 14. 
pre-cognitive dimension of ritual may also contribute to balancing the somewhat one-sided approach. ${ }^{15}$

Faculty of Theology, University of South Bohemia in České Budějovice Kněžská 8

37001 České Budějovice Czech Republic

E-mail: michaela.vlckova@icloud.com

15 " "If one asks ritualists what their rites and symbols mean, one quickly finds that there is little connection between how much can people articulate about a symbol's referents and how meaningful it is to them" writes Ronald Grimes, although he himself does not consider rituals to be purely pre-cognitive. He considers the body to be cognitive, not only an object, but a subject with its own way of questioning, arguing, asserting, thinking - its own form of wisdom.' Ronald Grimes, Reading, Writing and Ritualizing, Ritual in Fictive, Liturgical and Public Places (Washington D.C.: The Pastoral Press, 1993), 16, 19.

Catherine Bell describes the logic of ritual as 'inscribed in the body'. Bell, Ritual Theory, Ritual Practice, 101-107. 